\title{
Multiple Changes Induced by Fibroblasts on Breast Cancer Cells
}

\author{
Patrizia Cancemi, Nadia Ninfa Albanese, Gianluca Di Cara, Maria Rita Marabeti, \\ Francesca Costantini, and Salvatore Minafra \\ Dipartimento di Oncologia Sperimentale e Applicazioni Cliniche (DOSAC), Palermo, Italy
}

Ida Pucci-Minafra

DOSAC and Centro di Oncobiologia Sperimentale (COBS), Università di Palermo, Palermo, Italy

\begin{abstract}
It is now widely recognized that the cross-talk between cancer and stromal cells may play a crucial role in cancer progression. However, little is known about the complex underlying molecular mechanisms that occur within the tumor microenvironment. Fibroblasts are the major stromal cells with multiple roles, especially toward both the extracellular matrix and the neighboring cell population, including neoplastic cells. Consequently, proteomic analyses would provide a wider resource for a better understanding of the potential modulating effects exerted by fibroblasts on cancer cells. In this article we describe the effects of fibroblast stimulation on the breast cancer cell line (8701-BC) proteomics, using a trans-well coculture system. Our results clearly indicate that fibroblasts induce considerable proteomic modulations on 8701BC, mainly in the cytoskeleton proteins and glycolytic enzymes. Additionally, fibroblast-conditioned medium increased neoplastic cell proliferation and invasion with a concurrent upregulation of the c-Myc oncogene. Collectively these results suggest that fibroblast stimulation may enhance the malignant potential of breast cancer cells in vitro.
\end{abstract}

Keywords Proteomics; Breast Cancer Cells; Fibroblasts; Invasion Assay; Cell Proliferation

\section{INTRODUCTION}

Breast cancer, as other carcinomas, arises from epithelial cells through the sequential accumulation of multiple genetic modifications. Alterations in specific oncogenes and tumor suppressor genes have been identified and shown to have causal roles in the initiation, maintenance, and progression of breast

Received 22 April 2009; Revised 28 May 2009; Accepted 28 May 2009.

Address correspondence to Prof. Ida Pucci-Minafra, Dipartimento di Oncologia Sperimentale e Applicazioni Cliniche Via San Lorenzo Colli 312, 90146 Palermo, Italy. E-mail: idapucci@unipa.it cancer [1]. This genetic model of tumor progression, however, has largely ignored the substantial contribution of the tumor microenvironment to the metastatic phenotype. Indeed, during the invasion process, neoplastic cells cross the basal lamina and penetrate the underlying interstitial stroma where they may interact actively with the host cells [2]. Recent cancer studies have acknowledged the active roles that tumor stroma can play in carcinogenesis, focusing on the abnormal communication between tumor cells and their microenvironment (epigenetic model) [3-5]. A number of studies have reported that the proliferation and invasiveness of neoplastic cells can be negatively or positively regulated by the presence of adjacent stromal cells $[6,7]$. Several molecules, such as matrix metalloproteinases, growth factors, interleukins, chemokines, and collagens, have been recognized as participants to the tumor-stroma interplay [8-16], even though the molecular mechanisms underlying these cross-talks are not yet fully characterized.

In the past few years, the proteomic approach has attracted great attention because two-dimensional electrophoresis (2DIPG), the principal tool in proteomics, is able to resolve thousands of proteins at the same time. This allows the study of qualitative and quantitative variations between cells and tissues under given conditions [17, 18]. The aim of this study was to investigate the effects of soluble mediators released by fibroblasts in vitro on breast cancer cells, using a proteomic-based approach. As a model system we used the well-characterized breast cancer cell line 8701-BC [19] and healthy human fibroblasts as effector cells in a coculture system.

The fibroblastic effects on 8701-BC proteomic expression profiling, occurred as modulations of several classes of proteins, were identified by $\mathrm{N}$-terminal microsequencing and/or mass spectrometry analyses. Our results indicate that fibroblastderived signals can influence significantly the behavior of 8701BC breast cancer cells. Such changes appear to be associated with the acquisition of a more aggressive cell behavior and suggest a role of co-actors for fibroblasts during carcinogenesis. 


\section{MATERIALS AND METHODS}

\section{Cell Culture}

Breast cancer cell line 8701-BC and normal human dermal fibroblasts [20] were cultured on Dulbecco's Modified Eagle's Medium (D-MEM) supplemented with $10 \%$ fetal calf serum (FCS; GIBCO), L-glutamine $2 \mathrm{mM}$, and antibiotics (100 units/ml penicillin and $100 \mu \mathrm{g}$ streptomycin) in a humidified incubator with $5 \% \mathrm{CO}_{2}$ in air at $37^{\circ} \mathrm{C}$.

\section{Cell Proliferation Assay}

Cell proliferation was determined by the use of a colorimetric tetrazolium compound (CellTiter 96, Promega). Briefly, $20 \mu \mathrm{L}$ of CellTiter 96 was added to $100 \mu \mathrm{L}$ of medium into each well containing the cells. After $1 \mathrm{hr}$ of incubation in a humidified, $5 \% \mathrm{CO}_{2}$ atmosphere, the absorbance at $492 \mathrm{~nm}$ was read using a 96-well plate reader (Amersham).

\section{Conditioned Medium Preparation}

Conditioned medium from confluent fibroblasts was harvested after $24 \mathrm{hr}$ culture in D-MEM without serum, centrifuged to remove cell debris, and sterile filtered.

\section{Coculture Assays}

Cocultures of 8701-BC and fibroblasts were performed utilizing trans-well permeable supports (Costar), with $0.4 \mu \mathrm{m}$ pore size membrane. 8701-BC were seeded in the upper wells at $7.000 / \mathrm{cm}^{2}$, and fibroblasts in the lower wells at $13.000 / \mathrm{cm}^{2}$, grown separately until sub-confluence and then overlapped for $48 \mathrm{hr}$ without serum. Additional wells containing 8701-BC cells alone were similarly treated and used as controls.

\section{Protein Extraction from Cell Culture}

After washing with ice-cold phosphate buffered saline (PBS), cells were carefully scraped and incubated on ice for $30 \mathrm{~min}$ with RIPA buffer (50 mM Tris pH 7.5, 0.1\% Nonidet P-40, $0.1 \%$ deoxycholate, $150 \mathrm{mM} \mathrm{NaCl}, 4 \mathrm{mM}$ EDTA) and a mixture of protease inhibitors $(0.01 \%$ aprotinin, $10 \mathrm{mM}$ sodium pyrophosphate, $2 \mathrm{mM}$ sodium orthovanadate, $1 \mathrm{mM}$ PMSF). The total cellular lysate was centrifuged at $14,000 \mathrm{rpm}$ for $8 \mathrm{~min}$ to clear cell debris, and the supernatant dialyzed against ultrapure distilled water, lyophilized, and stored at $-80^{\circ} \mathrm{C}$ until analysis. Protein concentration in the cellular extracts was determined using the Bradford method [21].

\section{Two-Dimensional Gel Electrophoresis}

Aliquots of the dried cell lysate were solubilized in a buffer containing 4\% CHAPS, $40 \mathrm{mM}$ Tris, $65 \mathrm{mM}$ DTE (1,4-dithioerythritol), and a trace amount of bromophenol blue in $8 \mathrm{M}$ urea. The first dimensional separation was performed at $20^{\circ} \mathrm{C}$ on commercial sigmoidal immobilized $\mathrm{pH}$ gradient strips (IPG), $18 \mathrm{~cm}$ long with $\mathrm{pH}$ range 3.5 to 10 (Pharmacia). Strips were rehydrated in $8 \mathrm{M}$ urea, 2\% CHAPS, $10 \mathrm{mM}$ DTE, and $0.5 \%$ carrier ampholytes (Resolyte 3.5-10). Aliquots of $45 \mu \mathrm{g}$ (analytical gels) or $90 \mu \mathrm{g}$ (immunoblot gels) or $1 \mathrm{mg}$ (preparative gels) of total proteins were applied to the gel strip. The isoelectrofocusing was carried out by linearly increasing voltage from 200 to $3500 \mathrm{~V}$ during the first $3 \mathrm{hr}$, after which focusing was continued at $8000 \mathrm{~V}$ for $8 \mathrm{hr}$.

After the run the IPG strips were equilibrated with a solution containing $6 \mathrm{M}$ urea, 30\% glycerol, 2\% SDS, 0.05M Tris- $\mathrm{HCl}$ $\mathrm{pH} 6.8$, and 2\% DTE for $12 \mathrm{~min}$, to resolubilize proteins and reduce disulphuric bonds. The $-\mathrm{SH}$ groups were then blocked by substituting the DTE with $2.5 \%$ iodoacetamide in the equilibrating buffer. The focused proteins were then separated on $9-16 \%$ linear gradient polyacrylamide gels (SDS-PAGE) with a constant current of $40 \mathrm{~mA} / \mathrm{gel}$ at $10^{\circ} \mathrm{C}$. Gels were stained with ammoniacal silver nitrate, digitized using a computing densitometer, and processed with ImageMaster 2D-Platinum system (Amersham Biosciences).

\section{$\mathrm{N}$-Terminal Protein Sequencing}

$\mathrm{N}$-terminal microsequencing was performed by automated Edman degradation in a Protein Sequencer (Procise 491, Applied Biosystems) on protein samples electrotransferred onto PVDF membranes at $50 \mathrm{~V}$ for $30 \mathrm{~min}$ at $4{ }^{\circ} \mathrm{C}$. The Swissprot/TrEMBL/BLAST databases were used for online sequence similarity search at http://www. expasy.ch/tools/\#similarity.

\section{Matrix-Assisted Laser Desorption Ionization-Time of Flight (MALDI-TOF)}

Mass spectrometric sequencing was carried out after in-gel digestion of protein spots, using sequencing-grade trypsin (20 $\mu \mathrm{g} / \mathrm{vial}$ ), according to the method of Shevchenko et al. [22] with some modification. The tryptic peptide extracts were dried in a vacuum centrifuge and dissolved in $10 \mu \mathrm{L}$ of $0.1 \%$ trifluoroacetic acid (TFA). The matrix, R-cyano-4hydroxycinnamic acid (HCCA), was purchased from SigmaAldrich. A saturated solution of HCCA $(1 \mu \mathrm{L})$ at $2 \mathrm{mg} / 200$ $\mu \mathrm{L}$ in $\mathrm{CH}_{3} \mathrm{CN} / \mathrm{H}_{2} \mathrm{O}(50: 50(\mathrm{v} / \mathrm{v}))$ containing $0.1 \%$ TFA was mixed with $1 \mu \mathrm{L}$ of peptide solution on the MALDI plate and left to dry. MALDI-TOF mass spectra were recorded on a Voyager DE-PRO (Applied Biosystems) mass spectrometer, in the 500-5000 Da mass range, using a minimum of 100 shots of laser per spectrum. Delayed extraction source and reflector equipment allowed sufficient resolution to consider $\mathrm{MH}+$ of monoisotopic peptide masses. Internal calibration was done using trypsin autolysis fragments at m/z 842.5100, 1045.5642, and 2211.1046 Da.

Peptide mass fingerprinting was compared to the theoretical masses from the Swiss-Prot or NCBI sequence databases using Mascot (http://www.matrixscience.com/). Typical search parameters were as follows: $50 \mathrm{ppm}$ of mass tolerance, carbamidomethylation of cysteine residues, one missed enzymatic cleavage for trypsin, a minimum of four peptide mass hits was required for a match, methionine residues could be considered 
in oxidized form, no restriction was placed on the isoelectric point of the protein, and a protein mass range from 5 to $100 \mathrm{kDa}$ was allowed.

\section{Western Blotting}

For immune detection the gels were electrotransferred onto nitrocellulose membrane (HyBond ECL, Amersham) at $50 \mathrm{~V}$ for $1 \mathrm{hr}$ at $4^{\circ} \mathrm{C}$. After electrotransfer, the membranes were blocked with 5\% of dry milk in T-TBS for $1 \mathrm{hr}$ and probed with one of the following monoclonal antibodies diluted with $1 \%$ milk in T-TBS: c-MYC, G3P, and PARK7 from Santa Cruz; CK8 from Chemicon; and VIME from Novocastra. Following incubation with antimouse peroxidase-linked (Amersham), reaction was revealed using enhanced chemiluminescence (Pierce), according to the manufacturer's instructions.

For semiquantitative analyses ECL films were scanned in a gray scale mode. The pixel density was determined using ImageQuant TL software (Amersham) after background subtraction and used to calculate the integrated density of each selected band. Values of integrated density were reported in volume units of pixel intensity $/ \mathrm{cm}^{2}$. The integrated density for each band was calculated from three different film expositions.

\section{Cell Migration and Invasion Assay}

The invasion efficiency of 8701-BC cells was assayed using Boyden Chambers with the top side of filters filled with $15 \mu \mathrm{g}$ Matrigel. For migration, uncoated filters were used. Fibroblast-conditioned medium or D-MEM medium containing $1 \mathrm{mg} / \mathrm{ml}$ of BSA was placed in the lower compartments of Boyden chambers; $8701-\mathrm{BC}$ cells (150.000 cells) were placed in the upper compartments and incubated for $6 \mathrm{hr}$ in a humidified incubator with $5 \% \mathrm{CO}_{2}$ in air at $37^{\circ} \mathrm{C}$. Filters were then removed, fixed in ethanol, and stained with Toluidine blue. The cells corresponding to the upper filters were wiped off and the cells that had migrated or invaded through the pores to the lower side of the filters were counted in a blinded fashion using light microscopy at 200x magnification. Differences were considered significant at the ${ }^{*} p<0.05$ level.

\section{RESULTS AND DISCUSSION}

\section{Effect of Fibroblast-Conditioned Medium on 8701-BC Proliferation}

Cell proliferation was determined using the MTS colorimetric assay, at 24, 48, and $96 \mathrm{hr}, 5$ and 7 days. As shown in Figure 1A, after 7 days 8701 -BC are responsive to fibroblast stimulation, showing a significant increase of $\sim 58 \%$ with respect to the control cultures. This time point was chosen for the proteomic analysis. The increment of proliferation rate was associated with an increase of $\sim 45 \%$ in the expression of the oncoprotein c-myc, the most commonly amplified oncogene in human breast cancer [23] involved in the control of cellular growth [24]. Figure 1B shows a prototype of Western blot
(WB) assay for c-Myc and PARK7 expression in control and cocultured cells, run on the same gel. PARK7 protein was used as loading control, because of its unchanged proteomicexpression levels between control and cocultured cells. Figure 1C shows the relative quantification of the WB densitometric values of c-Myc normalized to the PARK7 protein expression level.

\section{Effect of Coculture on Protein Expression Profiles of 8701-BC}

Figure 2 shows the miniatures of the proteomic maps of 8701$\mathrm{BC}$ control and coculture. The protein identities are marked with labels corresponding to the abbreviated name of SwissProt database. One hundred sixty protein spots, corresponding to 97 distinct proteins, were identified in the maps. The protein identity was assessed by $\mathrm{N}$-terminal sequencing and by MALDI-TOF. The identified proteins are grouped into 11 functional categories, according to our previously described criteria $[17,25,26]$ : cytoskeleton and associated proteins, metabolic enzymes, molecular chaperones/heat shock proteins, membrane-associated proteins with multiple activities, calciumbinding proteins, proteins with binding function, biosynthesis and proliferation regulators, protein degradation, detoxification and redox proteins, proteins with extracellular activity, and signal transduction. The supplementary Table 1 reports the identified protein spots, displayed according to their functional category.

To compare the pattern and intensity of protein expression between 8701-BC control and cocultured cells, we carried out triplicate experiments to ensure reproducibility of results, and we applied the densitometric algorithm of the Image Master software, normalizing the data to the sum of all spot volumes on gels ( $\%$ vol) $[27,28]$. The quantitative analysis was performed on the 161 identified protein spots. According to our previously described criteria for gene expression amplitude, the degree of the modulation was considered high (**) for fold values $\geq 2$ and medium $\left({ }^{*}\right)$ for values between 2.0 and 1.5 [29].

Figure 3 displays the diagram of protein fold variation expressed in a logarithm scale and sorted by functional categories. The $77 \%$ of selected proteins showed no variation, while $23 \%$ were modulated, either positively $(12 \%)$ or negatively $(11 \%)$. In the group of cytoskeleton and associated proteins we identified 31 protein spots corresponding to 14 different proteins. Three of them, and their isoforms, are structural components of the cytoskeleton: actin, tubulin, and keratin. Furthermore, the identification of cytokeratin 8 (a marker of normal lumenal mammary cells) and vimentin (a marker for epithelium-mesenchymal transition) was performed by Western blot analyses, as reported below. The majority of the other proteins in this group correspond to actin-binding proteins (cofilin, ezrin, myosin light chain 6 , profilin-1, tropomyosin, and thymosin). 

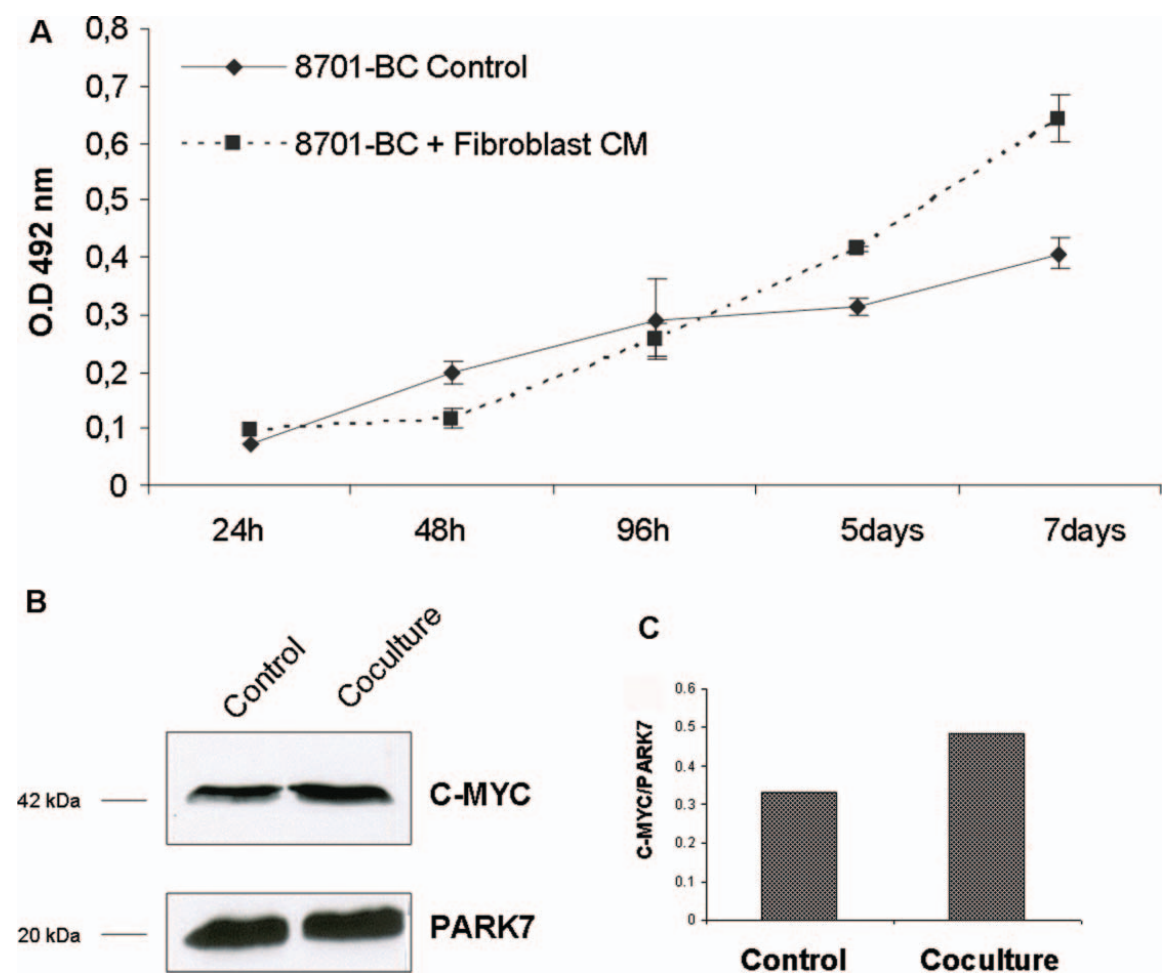

FIG. 1. (A) Diagram illustrates the growth rate of 8701-BC cells cultured in the presence (dotted line) or absence (continuos line) of fibroblast medium using the MTS colorimetric assay. Fibroblast stimulation induce a cell increament of $58 \%$ at 7 days vs. control cells. Each time point represents the mean of 3 replicates from three independent experiments $( \pm \mathrm{SD})$. (B) A prototype of 3 replicate Western blot (WB) assays for c-Myc and PARK7 protein expression in control and cocultured cells run on the same gels. (C) Diagram shows the relative quantification of the WB densitometric values of c-myc normalized to the PARK7 protein expression level.

Responsive proteins, defined as positive or negative modulations, corresponded to 11 of the 31 identified in this group. High levels of modulation were detected for tropomyosin 3 , one isoform of profilin 1, 1 isoform of tropomyosin 2 and myosin light polypeptide 6 . Moderately increased levels were detected for 3 actin isoforms, while moderately-decreased levels were found for one isoform of tropomyosin 4, for thymosin B4 and for 2 actin isoforms.

Most modulated proteins included the tropomyosin components. Tropomyosins are composed of alpha helix-subunits, which assemble into parallel homo- or heterodimeric coiled-coil structures. In human, the tropomyosins are coded by four homologue genes, TPM1, TPM2, TPM3, and TPM4, which may also generate a number of isoforms due to alternative splicing. Literature evidence suggests that selected combinations of these isoforms play important roles for actin cytoskeleton functions, such as cellular vesicle traffic, cell proliferation and apoptosis, and cell migration [30].

Interestingly, our results show different responses induced by fibroblastic stimulation on the tropomyosins subunits. Indeed, tropomyosin 1 was not modulated, whereas tropomyosin 2 and tropomyosin 3 were upregulated and tropomyosin 4 was downregulated.
The category of metabolic enzymes contains 36 spots, corresponding to 17 different enzymes and isoforms. Eight of these belong to the anaerobic glycolytic pathway, 4 are mitochondrial enzymes of the aerobic pathways, and the others (acyl-coA dehydrogenase, retinal dehydrogenase, enoyl-coA hydratase, and $\mathrm{N}(\mathrm{G}), \mathrm{N}(\mathrm{G})$-dimethylarginine dimethylaminohydrolase) belong to other metabolic pathways. Interestingly the majority of the proteins belonging to the glycolytic pathway (glyceraldehyde3-phosphate (G3P) dehydrogenase, triosephosphate isomerase, phosphoglycerate kinase 1) were upregulated, suggesting that the fibroblast-induced increment of cell proliferation is accompanied by a more marked metabolic shift toward glycolysis.

Due to the elevated number of different isoforms detected for G3P, Western blot analysis was performed on 2D gels, confirming the silver stained pattern of these protein isoforms (Figure 4). The observed increase of the glycolytic enzyme expression is concordant with the increment of c-Myc expression, which is known to activate (directly or indirectly) a number of genes related to the glycolytic pathway [31,32]. The elevated levels of anaerobic metabolism, even in the presence of oxygen, known as the "Warburg effect," is a frequent clinical syndrome in oncologic patients, an observation recognized by several 

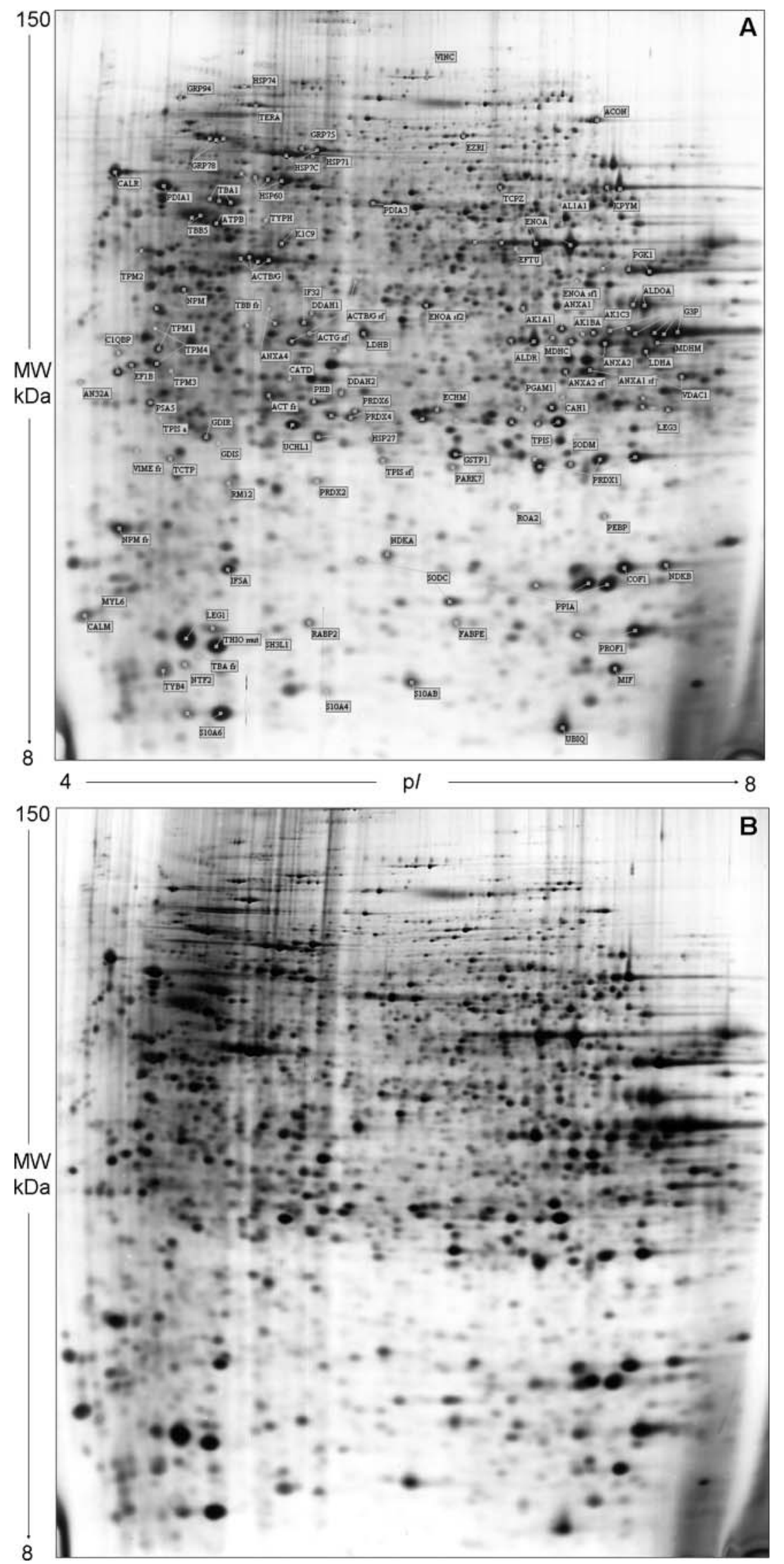

FIG. 2. Representative proteomic maps of 8701-BC control cells and cocultured with fibroblasts. 2-DE separation was performed on IPG gel strips (18 $\mathrm{cm}$, 3.5-10 NL) followed by the SDS-Page on a vertical linear-gradient slab gel (9-16\%T). Protein spots of known identity are labeled with the abbreviated name of the Swiss-Prot/TrEMBL database. When present, different isoforms of the same protein are jointly labeled. $\mathrm{sf}=$ short form; $\mathrm{Fr}=\mathrm{fragment}$. 
TABLE 1

Proteins identified on the $8701-\mathrm{BC}$ proteome

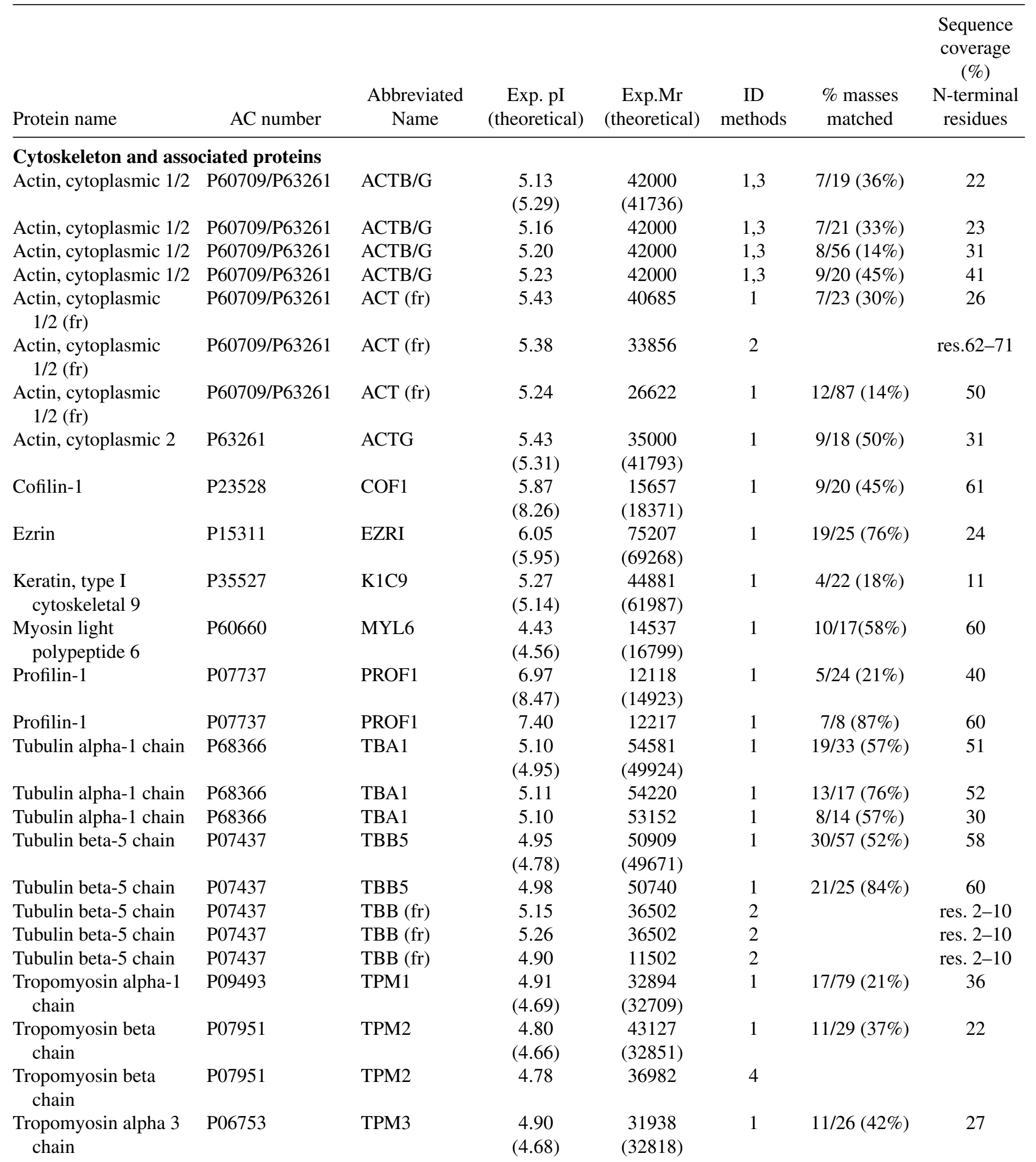


TABLE 1

Proteins identified on the 8701-BC proteome (Continued)

\begin{tabular}{|c|c|c|c|c|c|c|c|}
\hline Protein name & AC number & $\begin{array}{l}\text { Abbreviated } \\
\text { Name }\end{array}$ & $\begin{array}{c}\text { Exp. pI } \\
\text { (theoretical) }\end{array}$ & $\begin{array}{c}\text { Exp.Mr } \\
\text { (theoretical) }\end{array}$ & $\begin{array}{c}\text { ID } \\
\text { methods }\end{array}$ & $\begin{array}{l}\% \text { masses } \\
\text { matched }\end{array}$ & $\begin{array}{c}\text { Sequence } \\
\text { coverage } \\
(\%) \\
\text { N-terminal } \\
\text { residues }\end{array}$ \\
\hline $\begin{array}{l}\text { Tropomyosin alpha- } 4 \\
\text { chain }\end{array}$ & P67936 & TPM4 & $\begin{array}{c}4.77 \\
(4.67)\end{array}$ & $\begin{array}{c}36110 \\
(28391)\end{array}$ & 1 & $18 / 44(40 \%)$ & 43 \\
\hline $\begin{array}{l}\text { Tropomyosin alpha- } 4 \\
\text { chain }\end{array}$ & P67936 & TPM4 & 4.79 & 32869 & 4 & & \\
\hline Thymosin beta- 4 & P62328 & TYB4 & $\begin{array}{c}4.79 \\
(5.02)\end{array}$ & $\begin{array}{l}11252 \\
(4921)\end{array}$ & 4 & & \\
\hline Vinculin & P18206 & VINC & $\begin{array}{c}5.56 \\
(5.50)\end{array}$ & $\begin{array}{l}119845 \\
(123799)\end{array}$ & 1 & $23 / 146(16 \%)$ & 26 \\
\hline Vinculin & P18206 & VINC & 5.70 & 119845 & 1 & $29 / 118(25 \%)$ & 30 \\
\hline \multicolumn{8}{|l|}{ Metabolic enzymes } \\
\hline $\begin{array}{l}\text { Aconitate hydratase } \\
\text { mitochondrial }\end{array}$ & Q99798 & $\mathrm{ACON}$ & $\begin{array}{c}6.93 \\
(7.36)\end{array}$ & $\begin{array}{c}84876 \\
(85425)\end{array}$ & 1 & $17 / 29(58 \%)$ & 22 \\
\hline $\begin{array}{l}\text { Retinal } \\
\quad \text { dehydrogenase } 1\end{array}$ & P00352 & AL1A1 & $\begin{array}{c}6.80 \\
(6.29)\end{array}$ & $\begin{array}{l}50405 \\
(54731)\end{array}$ & 1 & $21 / 34(61 \%)$ & 49 \\
\hline $\begin{array}{l}\text { (fr)uctose- } \\
\text { bisphosphate } \\
\text { aldolase A }\end{array}$ & P04075 & ALDOA & $\begin{array}{c}5.27 \\
(8.39)\end{array}$ & $\begin{array}{c}38975 \\
(39289)\end{array}$ & 1 & $15 / 24(62 \%)$ & 59 \\
\hline $\begin{array}{l}\text { (fr)uctose- } \\
\text { bisphosphate } \\
\text { aldolase A }\end{array}$ & P04075 & ALDOA & 7.34 & 38913 & 1 & $4 / 10(40 \%)$ & 20 \\
\hline $\begin{array}{l}\text { ATP synthase subunit } \\
\text { beta, mitochondrial }\end{array}$ & P06576 & ATPB & $\begin{array}{c}5.05 \\
(5.26)\end{array}$ & $\begin{array}{l}50405 \\
(56560)\end{array}$ & 1 & $31 / 35(88 \%)$ & 59 \\
\hline $\begin{array}{l}\mathrm{N}(\mathrm{G}), \mathrm{N}(\mathrm{G})- \\
\text { dimethylarginine } \\
\text { dimethylaminohy- } \\
\text { drolase } 1\end{array}$ & O94760 & DDAH1 & $\begin{array}{c}5.35 \\
(5.53)\end{array}$ & $\begin{array}{l}36806 \\
(31122)\end{array}$ & 1 & $13 / 49(27 \%)$ & 56 \\
\hline $\begin{array}{l}\mathrm{N}(\mathrm{G}), \mathrm{N}(\mathrm{G})- \\
\text { dimethylarginine } \\
\text { dimethylaminohy- } \\
\text { drolase } 2\end{array}$ & O95865 & DDAH2 & $\begin{array}{c}5.39 \\
(5.66)\end{array}$ & $\begin{array}{l}27625 \\
(29644)\end{array}$ & 1 & $6 / 22(27 \%)$ & 35 \\
\hline $\begin{array}{l}\text { Enoyl-CoA hydratase, } \\
\text { mitochondrial }\end{array}$ & P30084 & ECHM & $\begin{array}{c}5.62 \\
(8.34)\end{array}$ & $\begin{array}{c}25751 \\
(31387)\end{array}$ & 2 & & res $28-37$ \\
\hline Alpha-enolase & P06733 & ENOA & $\begin{array}{c}6.03 \\
(6.99)\end{array}$ & $\begin{array}{c}47404 \\
(47037)\end{array}$ & 3 & & \\
\hline Alpha-enolase & P06733 & ENOA & 6.28 & 47225 & 3 & & \\
\hline Alpha-enolase & P06733 & ENOA & 6.56 & 47225 & 3 & & \\
\hline Alpha-enolase & P06733 & ENOA & 6.84 & 47225 & 3 & & \\
\hline Alpha-enolase (sf) & P06733 & ENOA (sf) & 5.59 & 38543 & 1 & $13 / 43(30 \%)$ & 35 \\
\hline Alpha-enolase (sf) & P06733 & ENOA (sf) & 6.79 & 41010 & 2 & & res $57-66$ \\
\hline $\begin{array}{l}\text { Glyceraldehyde-3- } \\
\text { phosphate }\end{array}$ & P04406 & G3P & $\begin{array}{c}7.09 \\
(8.58)\end{array}$ & $\begin{array}{c}36053 \\
(35922)\end{array}$ & 2 & & res $2-7$ \\
\hline
\end{tabular}

(Continued on next page) 
TABLE 1

Proteins identified on the 8701-BC proteome (Continued)

Sequence coverage

\begin{tabular}{|c|c|c|c|c|c|c|c|}
\hline Protein name & $\mathrm{AC}$ number & $\begin{array}{l}\text { Abbreviated } \\
\text { Name }\end{array}$ & $\begin{array}{c}\text { Exp. pI } \\
\text { (theoretical) }\end{array}$ & $\begin{array}{c}\text { Exp.Mr } \\
\text { (theoretical) }\end{array}$ & $\begin{array}{l}\text { ID } \\
\text { methods }\end{array}$ & $\begin{array}{l}\% \text { masses } \\
\text { matched }\end{array}$ & $\begin{array}{l}\text { N-terminal } \\
\text { residues }\end{array}$ \\
\hline $\begin{array}{l}\text { Glyceraldehyde-3- } \\
\text { phosphate } \\
\text { dehydrogenase }\end{array}$ & P04406 & G3P & 7.27 & 36110 & 2 & & res $2-11$ \\
\hline $\begin{array}{l}\text { Glyceraldehyde-3- } \\
\text { phosphate } \\
\text { dehydrogenase }\end{array}$ & P04406 & G3P & 7.39 & 36110 & 2 & & res $2-21$ \\
\hline $\begin{array}{l}\text { Glyceraldehyde-3- } \\
\text { phosphate } \\
\text { dehydrogenase }\end{array}$ & P04406 & G3P & 7.44 & 36053 & 2 & & res $2-11$ \\
\hline $\begin{array}{l}\text { Glyceraldehyde-3- } \\
\text { phosphate } \\
\text { dehydrogenase }\end{array}$ & P04406 & G3P & 7.52 & 36053 & 2 & & res $2-31$ \\
\hline $\begin{array}{l}\text { Pyruvate kinase } \\
\text { isozymes M1/M2 }\end{array}$ & P14618 & KPYM & $\begin{array}{c}7.03 \\
(7.95)\end{array}$ & $\begin{array}{c}61773 \\
(57805)\end{array}$ & 1 & $17 / 68(25 \%)$ & 39 \\
\hline $\begin{array}{l}\text { Pyruvate kinase } \\
\text { isozymes M1/M2 }\end{array}$ & P14618 & KPYM & 7.11 & 62478 & 1 & $25 / 28(89 \%)$ & 53 \\
\hline $\begin{array}{l}\text { L-lactate dehydrogenase } \\
\text { A chain }\end{array}$ & P00338 & LDHA & $\begin{array}{l}7.35 \\
(8.46)\end{array}$ & $\begin{array}{c}33982 \\
(36558)\end{array}$ & 1 & $8 / 23(34 \%)$ & 36 \\
\hline $\begin{array}{l}\text { L-lactate dehydrogenase } \\
\text { B chain }\end{array}$ & P07195 & LDHB & $\begin{array}{c}5.43 \\
(5.72)\end{array}$ & $\begin{array}{c}36053 \\
(36507)\end{array}$ & 1 & $15 / 30(50 \%)$ & 48 \\
\hline $\begin{array}{l}\text { Malate dehydrogenase, } \\
\text { cytoplasmic }\end{array}$ & P40925 & MDHC & $\begin{array}{c}6.70 \\
(8.92)\end{array}$ & $\begin{array}{c}36053 \\
(35831)\end{array}$ & 1 & $12 / 54(22 \%)$ & 37 \\
\hline $\begin{array}{l}\text { Malate dehydrogenase, } \\
\text { mitochondrial }\end{array}$ & P40926 & MDHM & $\begin{array}{c}7.41 \\
(8.92)\end{array}$ & $\begin{array}{c}34807 \\
(35531)\end{array}$ & 1 & $12 / 13(92 \%)$ & 50 \\
\hline $\begin{array}{l}\text { Phosphoglycerate } \\
\text { mutase } 1\end{array}$ & P18669 & PGAM1 & $\begin{array}{c}6.46 \\
(6.75)\end{array}$ & $\begin{array}{c}26524 \\
(28673)\end{array}$ & 1 & $11 / 28(39 \%)$ & 51 \\
\hline $\begin{array}{l}\text { Phosphoglycerate } \\
\text { mutase } 1\end{array}$ & P18669 & PGAM1 & 6.77 & 26524 & 1 & $14 / 29(48 \%)$ & 58 \\
\hline $\begin{array}{l}\text { Phosphoglycerate } \\
\text { kinase } 1\end{array}$ & P00558 & PGK 1 & $\begin{array}{c}7.08 \\
(8.30)\end{array}$ & $\begin{array}{c}41933 \\
(44483)\end{array}$ & 1 & $5 / 19(26 \%)$ & 17 \\
\hline $\begin{array}{l}\text { Phosphoglycerate } \\
\text { kinase } 1\end{array}$ & P00558 & PGK 1 & 7.25 & 42000 & 4 & & \\
\hline $\begin{array}{l}\text { Phosphoglycerate } \\
\text { kinase } 1\end{array}$ & P00558 & PGK 1 & 7.36 & 42000 & 1 & $5 / 16(31 \%)$ & 24 \\
\hline $\begin{array}{l}\text { Triosephosphate } \\
\text { isomerase }\end{array}$ & P60174 & TPIS & $\begin{array}{c}4.90 \\
(6.51)\end{array}$ & $\begin{array}{c}25581 \\
(26538)\end{array}$ & 1 & $10 / 15(66 \%)$ & 55 \\
\hline $\begin{array}{l}\text { Triosephosphate } \\
\text { isomerase }\end{array}$ & P60174 & TPIS & 5.47 & 22390 & 2 & & res $49-58$ \\
\hline $\begin{array}{l}\text { Triosephosphate } \\
\text { isomerase }\end{array}$ & P60174 & TPIS & 6.40 & 25000 & 2 & & res.1-9 \\
\hline $\begin{array}{l}\text { Triosephosphate } \\
\text { isomerase }\end{array}$ & P60174 & TPIS & 6.63 & 24921 & 2 & & res.3-11 \\
\hline $\begin{array}{l}\text { Triosephosphate } \\
\text { isomerase }\end{array}$ & P60174 & TPIS & 6.81 & 25000 & 2 & & res.2-6 \\
\hline $\begin{array}{r}\text { Triosephosphate } \\
\text { isomerase (sf) }\end{array}$ & P60174 & TPIS (sf) & 5.82 & 22035 & 2 & & res.49-58 \\
\hline
\end{tabular}


TABLE 1

Proteins identified on the 8701-BC proteome (Continued)

Sequence coverage

\begin{tabular}{|c|c|c|c|c|c|c|c|}
\hline Protein name & AC number & $\begin{array}{l}\text { Abbreviated } \\
\text { Name }\end{array}$ & $\begin{array}{c}\text { Exp.pI } \\
\text { (theoretical) }\end{array}$ & $\begin{array}{c}\text { Exp.Mr } \\
\text { (theoretical) }\end{array}$ & $\begin{array}{l}\text { ID } \\
\text { methods }\end{array}$ & $\begin{array}{l}\% \text { masses } \\
\text { matched }\end{array}$ & $\begin{array}{l}\text { N-terminal } \\
\text { residues }\end{array}$ \\
\hline \multicolumn{8}{|c|}{ Molecular chaperones/Heat shock proteins } \\
\hline Calreticulin & P27797 & CALR & $\begin{array}{c}4.52 \\
(4.29)\end{array}$ & $\begin{array}{c}62007 \\
(48142)\end{array}$ & 1 & $21 / 168(12 \%)$ & 58 \\
\hline $\begin{array}{l}75 \mathrm{kDa} \text { glucose- } \\
\text { regulated protein }\end{array}$ & P38646 & GRP75 & $\begin{array}{c}5.30 \\
(5.87)\end{array}$ & $\begin{array}{c}73791 \\
(73681)\end{array}$ & 1 & $14 / 17(82 \%)$ & 24 \\
\hline $\begin{array}{l}78 \mathrm{kDa} \text { glucose- } \\
\text { regulated protein }\end{array}$ & P11021 & GRP78 & $\begin{array}{c}4.97 \\
(5.07)\end{array}$ & $\begin{array}{c}75771 \\
(72333)\end{array}$ & 4 & & \\
\hline $\begin{array}{l}78 \mathrm{kDa} \text { glucose- } \\
\text { regulated protein }\end{array}$ & P11021 & GRP78 & 5.01 & 76058 & 1 & $28 / 42(66 \%)$ & 49 \\
\hline $\begin{array}{l}78 \mathrm{kDa} \text { glucose- } \\
\text { regulated protein }\end{array}$ & P11021 & GRP78 & 5.04 & 76058 & 1 & 13/17 (76\%) & 25 \\
\hline $\begin{array}{l}94 \mathrm{kDa} \text { glucose- } \\
\text { regulated protein }\end{array}$ & $\mathrm{P} 14625$ & GRP94 & $\begin{array}{c}4.90 \\
(4.76)\end{array}$ & $\begin{array}{c}91200 \\
(92469)\end{array}$ & 4 & & \\
\hline $\begin{array}{l}\text { Heat shock protein } \\
\text { beta- } 1\end{array}$ & P04792 & HSP27 & $\begin{array}{c}5.43 \\
(5.98)\end{array}$ & $\begin{array}{c}24530 \\
(22783)\end{array}$ & 1 & $6 / 22(27 \%)$ & 29 \\
\hline $\begin{array}{l}\text { Heat shock protein } \\
\text { beta-1 }\end{array}$ & P04792 & HSP27 & 5.54 & 24569 & 1 & $12 / 39(31 \%)$ & 52 \\
\hline $\begin{array}{l}\text { Heat shock protein } \\
\text { beta-1 }\end{array}$ & P04792 & HSP27 & 5.55 & 24031 & 1 & $12 / 23(52 \%)$ & 61 \\
\hline $\begin{array}{l}60 \mathrm{kDa} \text { heat shock } \\
\text { protein, } \\
\text { mitochondrial }\end{array}$ & P10809 & HSP60 & $\begin{array}{c}5.19 \\
(5.27)\end{array}$ & $\begin{array}{c}61773 \\
(59500)\end{array}$ & 4 & & \\
\hline $\begin{array}{l}60 \mathrm{kDa} \text { heat shock } \\
\text { protein, } \\
\text { mitochondrial }\end{array}$ & P10809 & HSP60 & 5.24 & 62007 & 2 & & res $33-38$ \\
\hline $\begin{array}{l}60 \mathrm{kDa} \text { heat shock } \\
\text { protein, } \\
\text { mitochondrial }\end{array}$ & P10809 & HSP60 & 5.23 & 59500 & 2 & & res $33-38$ \\
\hline $\begin{array}{l}60 \mathrm{kDa} \text { heat shock } \\
\text { protein, } \\
\text { mitochondrial }\end{array}$ & P10809 & HSP60 & 5.27 & 59500 & 1,2 & $15 / 19(78 \%)$ & $\begin{array}{c}\text { res } 33-38 \\
39\end{array}$ \\
\hline $\begin{array}{l}\text { Heat shock } 70 \mathrm{kDa} \\
\text { protein } 1\end{array}$ & P08107 & HSP71 & $\begin{array}{c}5.33 \\
(5.48)\end{array}$ & $\begin{array}{c}70251 \\
(70052)\end{array}$ & 4 & & \\
\hline $\begin{array}{l}\text { Heat shock } 70 \mathrm{kDa} \\
\text { protein } 4\end{array}$ & P34932 & HSP74 & $\begin{array}{c}5.12 \\
(5.18)\end{array}$ & $\begin{array}{l}110395 \\
(94300)\end{array}$ & 1 & $10 / 17(58 \%)$ & 18 \\
\hline $\begin{array}{l}\text { Heat shock cognate } 71 \\
\text { kDa protein }\end{array}$ & P11142 & HSP7C & $\begin{array}{c}5.27 \\
(5.38)\end{array}$ & $\begin{array}{c}71322 \\
(70898)\end{array}$ & 1 & $24 / 34(70 \%)$ & 43 \\
\hline $\begin{array}{l}\text { Heat shock cognate } 71 \\
\text { kDa protein }\end{array}$ & P11142 & HSP7C & 5.34 & 73791 & 1 & $19 / 50(38 \%)$ & 38 \\
\hline $\begin{array}{l}\text { Parkinson disease } \\
\text { protein 7-Oncogene } \\
\text { DJ1 }\end{array}$ & Q99497 & PARK7 & $\begin{array}{c}5.79 \\
(6.33)\end{array}$ & $\begin{array}{c}21164 \\
(19891)\end{array}$ & 1 & $11 / 41(27 \%)$ & 66 \\
\hline $\begin{array}{l}\text { Protein } \\
\quad \text { disulfide-isomerase }\end{array}$ & P07237 & PDIA1 & $\begin{array}{c}4.85 \\
(4.76)\end{array}$ & $\begin{array}{c}59480 \\
(57117)\end{array}$ & 1 & $4 / 12(33 \%)$ & 9 \\
\hline $\begin{array}{l}\text { Protein disulfide- } \\
\text { isomerase A3 }\end{array}$ & P30101 & PDIA3 & $\begin{array}{r}5.45 \\
(5.9)\end{array}$ & $\begin{array}{c}55566 \\
(56783)\end{array}$ & 1 & $11 / 19(57 \%)$ & 21 \\
\hline
\end{tabular}


TABLE 1

Proteins identified on the 8701-BC proteome (Continued)

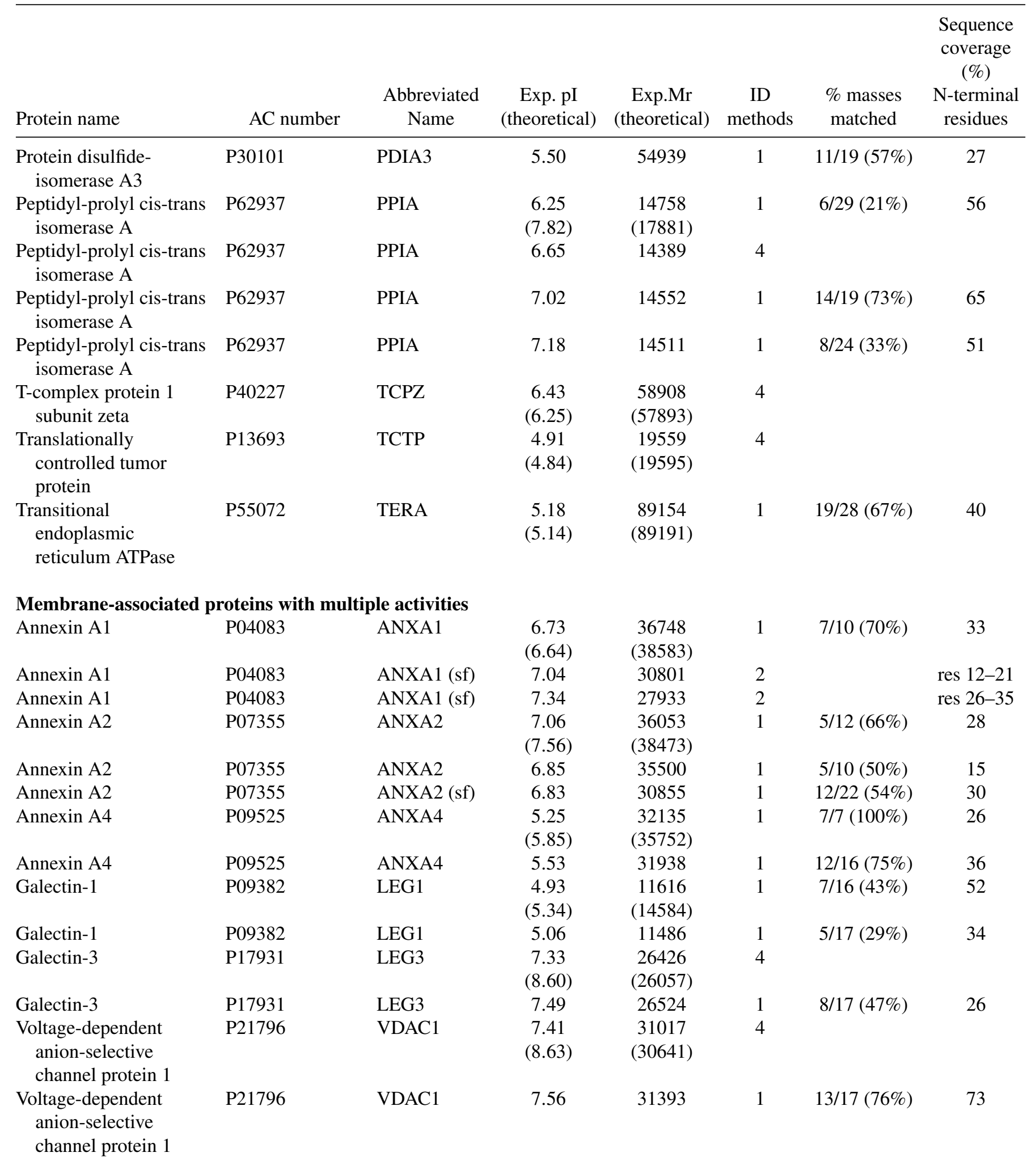


TABLE 1

Proteins identified on the 8701-BC proteome (Continued)

Sequence coverage

\begin{tabular}{|c|c|c|c|c|c|c|c|}
\hline Protein name & $\mathrm{AC}$ number & $\begin{array}{l}\text { Abbreviated } \\
\text { Name }\end{array}$ & $\begin{array}{c}\text { Exp.pI } \\
\text { (theoretical) }\end{array}$ & $\begin{array}{c}\text { Exp.Mr } \\
\text { (theoretical) }\end{array}$ & $\begin{array}{l}\text { ID } \\
\text { methods }\end{array}$ & $\begin{array}{l}\% \text { masses } \\
\text { matched }\end{array}$ & $\begin{array}{l}\text { N-terminal } \\
\text { residues }\end{array}$ \\
\hline \multicolumn{8}{|c|}{ Calcium binding proteins } \\
\hline Calmodulin & P62158 & CALM & $\begin{array}{c}4.36 \\
(4.09)\end{array}$ & $\begin{array}{l}12118 \\
(16706)\end{array}$ & 1 & $6 / 20(30 \%)$ & 54 \\
\hline Protein S100-A4 & P26447 & S10A4 & $\begin{array}{c}5.39 \\
(5.85)\end{array}$ & $\begin{array}{c}9352 \\
(11729)\end{array}$ & 1 & $6 / 16(37 \%)$ & 45 \\
\hline Protein S100-A6 & P06703 & S10A6 & $\begin{array}{c}4.96 \\
(5.32)\end{array}$ & $\begin{array}{c}8790 \\
(10180)\end{array}$ & 1 & $3 / 16(18 \%)$ & 26 \\
\hline Protein S100-A6 & P06703 & S10A6 & 5.09 & 8765 & 4 & & \\
\hline Protein S100-A11 & P31949 & S10AB & $\begin{array}{c}5.55 \\
(6.56)\end{array}$ & $\begin{array}{c}9728 \\
(11740)\end{array}$ & 1 & $5 / 11(45 \%)$ & 42 \\
\hline \multicolumn{8}{|c|}{ Proteins with binding functions } \\
\hline $\begin{array}{l}\text { Fatty acid-binding } \\
\text { protein, epidermal }\end{array}$ & Q01469 & FABP5 & $\begin{array}{c}5.91 \\
(6.60)\end{array}$ & $\begin{array}{l}11948 \\
(15164)\end{array}$ & 1 & $8 / 23(34 \%)$ & 52 \\
\hline $\begin{array}{l}\text { Phosphatidylethanol- } \\
\text { amine-binding } \\
\text { protein } 1\end{array}$ & P30086 & PEBP1 & $\begin{array}{c}6.88 \\
(7.43)\end{array}$ & $\begin{array}{c}19123 \\
(20965)\end{array}$ & 2 & & res. $1-10$ \\
\hline $\begin{array}{l}\text { Cellular retinoic } \\
\text { acid-binding } \\
\text { protein } 2\end{array}$ & P29373 & RABP2 & $\begin{array}{c}5.35 \\
(4.73)\end{array}$ & $\begin{array}{l}12118 \\
(27745)\end{array}$ & 2 & & res. $1-10$ \\
\hline $\begin{array}{l}\text { Complement } \\
\text { component } 1 \mathrm{Q} \\
\text { subcomponent- } \\
\text { binding protein, } \\
\text { mitochondrial }\end{array}$ & Q07021 & C1QBP & $\begin{array}{c}4.54 \\
(4.74)\end{array}$ & $\begin{array}{c}31231 \\
(31362)\end{array}$ & 2 & & res $74-84$ \\
\hline $\begin{array}{l}\text { Complement } \\
\text { component } 1 \mathrm{Q} \\
\text { subcomponent- } \\
\text { binding protein, } \\
\text { mitochondrial }\end{array}$ & Q07021 & C1QBP & 4.54 & 30855 & 1 & $7 / 32(22 \%)$ & 40 \\
\hline $\begin{array}{l}\text { Biosynthesis and } \\
\text { proliferation } \\
\text { regulators }\end{array}$ & & & & & & & \\
\hline $\begin{array}{l}\text { Acidic leucine-rich } \\
\text { nuclear } \\
\text { phosphoprotein } 32 \\
\text { family member A }\end{array}$ & P39687 & AN32A & $\begin{array}{l}4.15 \\
(3.99)\end{array}$ & $\begin{array}{l}28703 \\
(28585)\end{array}$ & 1 & $10 / 35(29 \%)$ & 30 \\
\hline $\begin{array}{l}\text { Elongation factor } \\
\text { 1-beta }\end{array}$ & P24534 & $\mathrm{EF} 1 \mathrm{~B}$ & $\begin{array}{c}4.65 \\
(4.50)\end{array}$ & $\begin{array}{c}30413 \\
(24632)\end{array}$ & 1 & $10 / 10(100 \%)$ & 46 \\
\hline $\begin{array}{l}\text { Elongation factor } \mathrm{Tu}, \\
\text { mitochondrial }\end{array}$ & P49411 & EFTU & $\begin{array}{c}6.52 \\
(5.38)\end{array}$ & $\begin{array}{c}44881 \\
(36502)\end{array}$ & 2 & & res $44-52$ \\
\hline $\begin{array}{l}\text { Eukaryotic translation } \\
\text { initiation factor } 3 \\
\text { subunit } 2\end{array}$ & Q13347 & IF32 & $\begin{array}{c}5.44 \\
(5.38)\end{array}$ & $\begin{array}{c}36502 \\
(36502)\end{array}$ & 1 & $13 / 45(28 \%)$ & 52 \\
\hline $\begin{array}{c}\text { Eukaryotic translation } \\
\text { initiation factor } 5 \mathrm{~A}\end{array}$ & P63241 & IF5A & $\begin{array}{c}5.08 \\
(5.08)\end{array}$ & $\begin{array}{c}14897 \\
(16701)\end{array}$ & 1 & $12 / 31(38 \%)$ & 67 \\
\hline
\end{tabular}


TABLE 1

Proteins identified on the 8701-BC proteome (Continued)

Sequence coverage

\begin{tabular}{|c|c|c|c|c|c|c|c|}
\hline Protein name & $\mathrm{AC}$ number & $\begin{array}{l}\text { Abbreviated } \\
\text { Name }\end{array}$ & $\begin{array}{c}\text { Exp. pI } \\
\text { (theoretical) }\end{array}$ & $\begin{array}{l}\text { Exp.Mr } \\
\text { (theoretical) }\end{array}$ & $\begin{array}{l}\text { ID } \\
\text { methods }\end{array}$ & $\begin{array}{l}\% \text { masses } \\
\text { matched }\end{array}$ & $\begin{array}{l}\mathrm{N} \text {-terminal } \\
\text { residues }\end{array}$ \\
\hline $\begin{array}{l}\text { Nucleoside diphosphate } \\
\text { kinase A }\end{array}$ & P15531 & NDKA & $\begin{array}{c}5.49 \\
(5.83)\end{array}$ & $\begin{array}{c}17673 \\
(17149)\end{array}$ & 1 & $8 / 37(21 \%)$ & 52 \\
\hline $\begin{array}{l}\text { Nucleoside diphosphate } \\
\text { kinase B }\end{array}$ & P22392 & NDKB & $\begin{array}{c}7.52 \\
(8.52)\end{array}$ & $\begin{array}{c}15613 \\
(17298)\end{array}$ & 1 & 10/17 (58\%) & 56 \\
\hline Nucleophosmin & P06748 & NPM & $\begin{array}{c}4.92 \\
(4.64)\end{array}$ & $\begin{array}{c}38913 \\
(32675)\end{array}$ & 1 & $8 / 15(53 \%)$ & 28 \\
\hline Nucleophosmin (fr) & P06748 & NPM (fr) & 4.46 & 16963 & 1 & $6 / 10(60 \%)$ & 23 \\
\hline $\begin{array}{l}\text { Nuclear transport } \\
\text { factor } 2\end{array}$ & P61970 & NTF2 & $\begin{array}{l}4.95 \\
(5.10)\end{array}$ & $\begin{array}{c}10437 \\
(14478)\end{array}$ & 1 & $7 / 19(37 \%)$ & 53 \\
\hline Prohibitin & P35232 & PHB & $\begin{array}{l}5.35 \\
(5.57)\end{array}$ & $\begin{array}{l}25186 \\
(29804)\end{array}$ & 1 & $9 / 16(56 \%)$ & 58 \\
\hline $\begin{array}{l}\text { 39S ribosomal protein } \\
\text { L12 }\end{array}$ & P52815 & RM12 & $\begin{array}{c}5.09 \\
(9.05)\end{array}$ & $\begin{array}{l}19355 \\
(21348)\end{array}$ & 4 & & \\
\hline $\begin{array}{l}\text { Heterogeneous nuclear } \\
\text { ribonucleoproteins } \\
\text { A2/B1 }\end{array}$ & P22626 & ROA2 & $\begin{array}{c}6.59 \\
(8.97)\end{array}$ & $\begin{array}{c}17426 \\
(37429)\end{array}$ & 1 & $15 / 122(12 \%)$ & 31 \\
\hline $\begin{array}{l}\text { SH3 domain-binding } \\
\text { glutamic } \\
\text { acid-rich-like protein }\end{array}$ & O75368 & SH3L1 & $\begin{array}{c}5.23 \\
(5.22)\end{array}$ & $\begin{array}{c}11918 \\
(12643)\end{array}$ & 2 & & res. $2-11$ \\
\hline $\begin{array}{l}\text { Thymidine } \\
\text { phosphorylase }\end{array}$ & P19971 & TYPH & 5.23 & 52105 & 1 & $6 / 8(75 \%)$ & 20 \\
\hline Protein degradation & & & $(5.36)$ & $(49955)$ & & & \\
\hline $\begin{array}{l}\text { Proteasome subunit } \\
\text { alpha type- } 5\end{array}$ & P28066 & PSA5 & $\begin{array}{c}4.76 \\
(4.74)\end{array}$ & $\begin{array}{c}25751 \\
(26411)\end{array}$ & 2 & & res. $4-13$ \\
\hline Ubiquitin & P62988 & UBIQ & $\begin{array}{c}6.87 \\
(5.56)\end{array}$ & $\begin{array}{c}8594 \\
(8583)\end{array}$ & 2 & & res. $1-15$ \\
\hline $\begin{array}{l}\text { Ubiquitin } \\
\text { carboxyl-terminal } \\
\text { hydrolase isozyme L1 }\end{array}$ & P09936 & UCHL1 & $\begin{array}{c}5.30 \\
(5.33)\end{array}$ & $\begin{array}{l}24414 \\
(24824)\end{array}$ & 1 & 10/14 (71\%) & 67 \\
\hline \multicolumn{8}{|c|}{ Detoxification and redox proteins } \\
\hline $\begin{array}{l}\text { Aldo-keto reductase } \\
\text { family } 1 \text { member A1 }\end{array}$ & P14550 & AK1A1 & $\begin{array}{c}6.47 \\
(6.32)\end{array}$ & $\begin{array}{c}38299 \\
(36573)\end{array}$ & 1 & $7 / 20(35 \%)$ & 28 \\
\hline $\begin{array}{l}\text { Aldo-keto reductase } \\
\text { family } 1 \text { member B10 }\end{array}$ & O60218 & AK1BA & $\begin{array}{c}6.90 \\
(7.12)\end{array}$ & $\begin{array}{c}35289 \\
(36021)\end{array}$ & 1 & $6 / 14(42 \%)$ & 25 \\
\hline $\begin{array}{l}\text { Aldo-keto reductase } \\
\text { family } 1 \text { member B10 }\end{array}$ & O60218 & AK1BA & 6.99 & 35500 & 1 & 7/18 (38\%) & 36 \\
\hline $\begin{array}{l}\text { Aldo-keto reductase } \\
\text { family } 1 \text { member C3 }\end{array}$ & P42330 & AK1C3 & $\begin{array}{l}7.23 \\
(8.05)\end{array}$ & $\begin{array}{c}35652 \\
(36844)\end{array}$ & 1 & - & 30 \\
\hline Aldose reductase & P15121 & ALDR & $\begin{array}{c}6.40 \\
(6.55)\end{array}$ & $\begin{array}{c}35920 \\
(35722)\end{array}$ & 1 & $3 / 10(30 \%)$ & 21 \\
\hline Aldose reductase & P15121 & ALDR & 6.57 & 36053 & 1 & $8 / 14(57 \%)$ & 41 \\
\hline Carbonic anhydrase 1 & P00915 & CAH1 & $\begin{array}{c}6.89 \\
(6.63)\end{array}$ & $\begin{array}{l}27946 \\
(28870)\end{array}$ & 1 & 13/78 (17\%) & 65 \\
\hline $\begin{array}{l}\text { Glutathione } \\
\text { S-tran(sf)erase P }\end{array}$ & P09211 & GSTP1 & $\begin{array}{c}5.36 \\
(5.44)\end{array}$ & $\begin{array}{c}23356 \\
(23225)\end{array}$ & 2 & & res $1-10$ \\
\hline
\end{tabular}


TABLE 1

Proteins identified on the 8701-BC proteome (Continued)

Sequence

coverage

\begin{tabular}{|c|c|c|c|c|c|c|c|}
\hline Protein name & AC number & $\begin{array}{l}\text { Abbreviated } \\
\text { Name }\end{array}$ & $\begin{array}{c}\text { Exp.pI } \\
\text { (theoretical) }\end{array}$ & $\begin{array}{l}\text { Exp.Mr } \\
\text { (theoretical) }\end{array}$ & $\begin{array}{l}\text { ID } \\
\text { methods }\end{array}$ & $\begin{array}{l}\% \text { masses } \\
\text { matched }\end{array}$ & $\begin{array}{l}\mathrm{N} \text {-terminal } \\
\text { residues }\end{array}$ \\
\hline Peroxiredoxin-1 & Q06830 & PRDX1 & $\begin{array}{c}6.76 \\
(8.27)\end{array}$ & $\begin{array}{c}20518 \\
(22110)\end{array}$ & 1 & $14 / 133(11 \%)$ & 73 \\
\hline Peroxiredoxin-1 & Q06830 & PRDX1 & 7.07 & 22771 & 1 & $7 / 11(63 \%)$ & 45 \\
\hline Peroxiredoxin-1 & Q06830 & PRDX1 & 7.34 & 23094 & 1 & $14 / 19(73 \%)$ & 55 \\
\hline Peroxiredoxin-2 & P32119 & PRDX2 & $\begin{array}{c}5.11 \\
(5.66)\end{array}$ & $\begin{array}{l}18803 \\
(21891)\end{array}$ & 1 & 10/55 (18\%) & 36 \\
\hline Peroxiredoxin-4 & Q13162 & PRDX4 & $\begin{array}{c}5.68 \\
(5.86)\end{array}$ & $\begin{array}{c}25581 \\
(30540)\end{array}$ & 1 & $13 / 145(9 \%)$ & 57 \\
\hline Peroxiredoxin 6 & P30041 & PRDX6 & $\begin{array}{l}5.67 \\
(6.02)\end{array}$ & $\begin{array}{l}26680 \\
(24904)\end{array}$ & 1 & $8 / 15(53 \%)$ & 34 \\
\hline $\begin{array}{l}\text { Superoxide dismutase } \\
\text { [Cu-Zn] }\end{array}$ & P00441 & SODC & $\begin{array}{c}5.43 \\
(5.70)\end{array}$ & $\begin{array}{c}15924 \\
(15804)\end{array}$ & 1 & $6 / 27(22 \%)$ & 73 \\
\hline $\begin{array}{l}\text { Superoxide dismutase } \\
\quad[\mathrm{Cu}-\mathrm{Zn}]\end{array}$ & P00441 & SODC & 6.91 & 22264 & 2 & & res. $25-34$ \\
\hline $\begin{array}{l}\text { Superoxide dismutase } \\
{[\mathrm{Mn}], \text { mitochondrial }}\end{array}$ & P04179 & SODM & $\begin{array}{c}6.72 \\
(8.35)\end{array}$ & $\begin{array}{l}20760 \\
(24722)\end{array}$ & 4 & & \\
\hline $\begin{array}{l}\text { Superoxide dismutase } \\
{[\mathrm{Mn}], \text { mitochondrial }}\end{array}$ & P04179 & SODM & 6.88 & 20634 & 1 & $8 / 16(50 \%)$ & 50 \\
\hline Thioredoxin & P10599 & THIO & $\begin{array}{c}4.97 \\
(4.82)\end{array}$ & $\begin{array}{c}11230 \\
(11606)\end{array}$ & 2 & & res $1-10$ \\
\hline \multicolumn{8}{|c|}{ Proteins with extracellular activity } \\
\hline Cathepsin D & P07339 & CATD & $\begin{array}{c}5.27 \\
(5.56)\end{array}$ & $\begin{array}{l}28560 \\
(26628)\end{array}$ & 1 & $17 / 44(39 \%)$ & 41 \\
\hline $\begin{array}{l}\text { Macrophage Migration } \\
\text { Inhibitory Factor } \\
\text { Signal transduction }\end{array}$ & P14174 & MIF & $\begin{array}{l}7.30 \\
(8.24)\end{array}$ & $\begin{array}{l}11350 \\
(12345)\end{array}$ & 1 & $4 / 20(20 \%)$ & 23 \\
\hline $\begin{array}{l}\text { Rho GDP-dissociation } \\
\text { inhibitor } 1\end{array}$ & P52565 & GDIR & $\begin{array}{c}5.02 \\
(5.03)\end{array}$ & $\begin{array}{c}23430 \\
(23207)\end{array}$ & 1 & $7 / 31(23 \%)$ & 38 \\
\hline $\begin{array}{l}\text { Rho GDP-dissociation } \\
\text { inhibitor } 2\end{array}$ & P52566 & GDIS & $\begin{array}{c}5.09 \\
(5.10)\end{array}$ & $\begin{array}{c}22643 \\
(22988)\end{array}$ & 1 & $11 / 39(28 \%)$ & 64 \\
\hline
\end{tabular}

ID Methods: 1 Maldi; 2 Nt-microsequencing; 3 Western Blot; 4 Gel matching with our previous published maps.

authors, including our group [17, 25, 26], as a frequent feature of neoplastic cells both in vivo and in vitro.

It is also note worthy that the enzyme retinal dehydrogenase (ALIA1), which is a breast cancer stem cell marker, remains unchanged after fibroblast stimulation. This further suggests that, in this context, fibroblasts are unable to revert the malignant phenotype of breast cancer cells 8701-BC.

Within the group of molecular chaperones/heat shock proteins we detected 28 spots corresponding to 16 proteins. Generally, heat shock protein (HSP) levels increase under conditions of cellular stress to provide cellular protection and maintain homeostasis. HSPs act as "molecular chaperones," by assisting protein folding, transport, and degradation. But during stress, they prevent aggregation and promote the refolding of damaged proteins. Surprisingly, only one protein form, protein disulfide-isomerase 3 (PDIA3), was found significantly upregulated in coculture, while 5 proteins of this category decreased their expression and the others remained unaffected, suggesting that fibroblastic effects on neoplastic cells do not drive stress-related activities. 


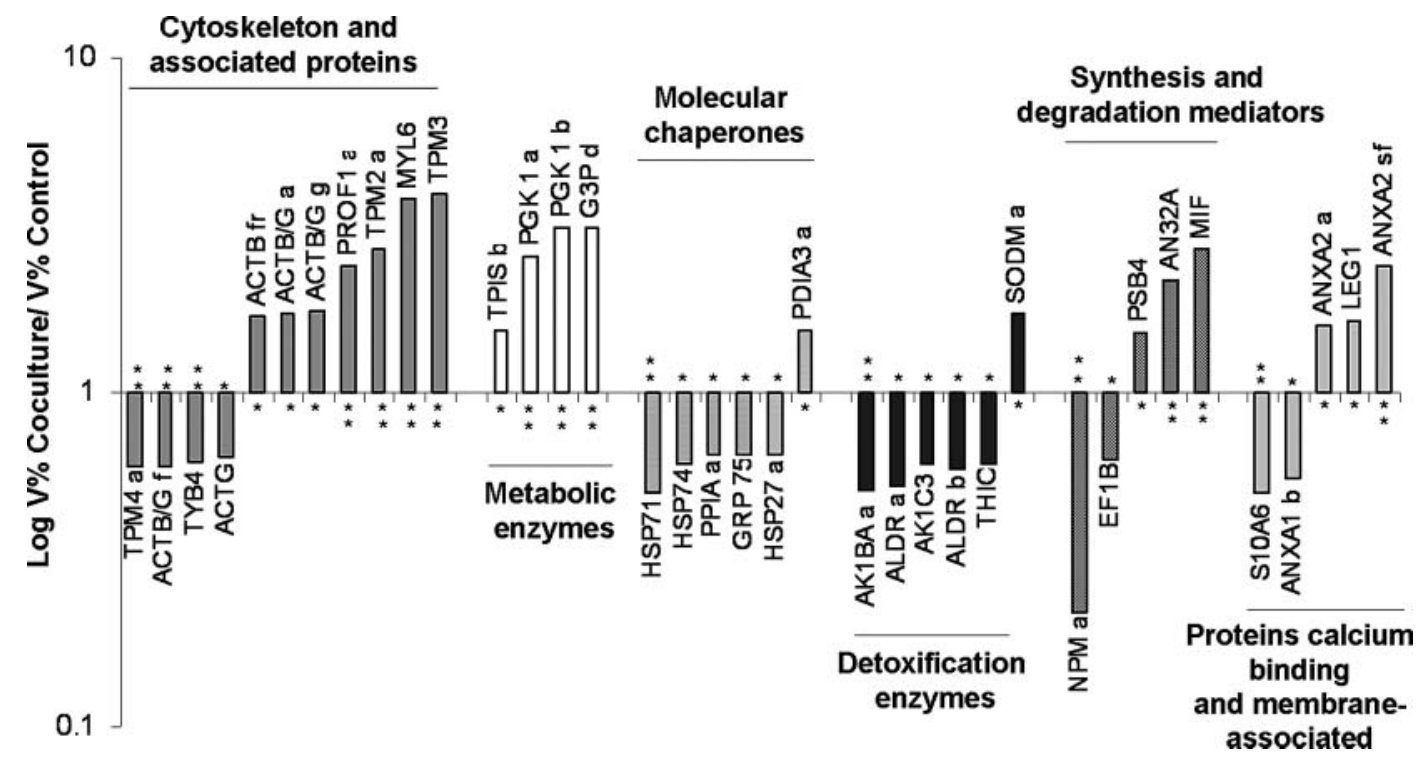

FIG. 3. Diagram presents protein fold variation between cocultured and control cells, expressed in a logarithm scale and sorted by functional categories alphabetic letters after the protein names indicate the isoelectric forms (when present) from more acidic (a) to more basic pH. Relative intensity of protein spots was calculated normalizing the data to the sum of all spot volumes on gels (vol\%). Each value is the mean of three independent determinations. For graphical limitations the SD values (5-10\%) were not included in this figure. According to general criteria for gene expression amplitude, the degree of the modulation was considered high $(* *)$ for fold values $\geq 2$ and medium $(*)$ for values between 2.0 and 1.5 .

The disulfide-isomerase protein is a multifunctional chaperone present both in the cytosol and at the cell surface where it mediates integrin-dependent cell adhesion [33]. Interestingly, PDI was identified to play an important role in glioma cell invasion [34]. To our knowledge this is the first report suggesting that fibroblasts may enhance PDI in cancer cells, possibly potentiating their invasive behaviour.

Membrane-associated proteins with multiple activities include the annexins, galectins, and the voltage-dependent anionselective channel protein 1. Among this group, galectin-1, annexin A2, and a short form of it (ANX2LC) were found increased in the cocultured cells, while annexin A1 showed decreased expression. Annexin A2 is a ubiquitous $\mathrm{Ca}^{2+}$-binding protein shown to be involved in several cellular processes such as cell motility and actin-dependent vesicle transport. In general it has an essential role in maintaining the plasticity of the dynamic membrane-associated actin cytoskeleton [35]. Conversely, the

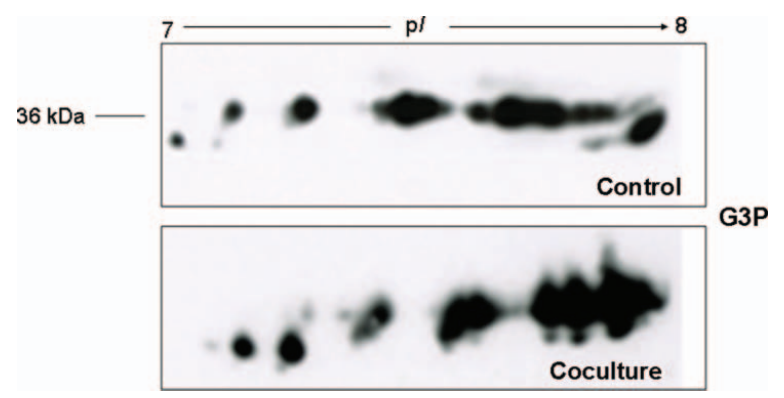

FIG. 4. 2D-Western blot shows different isoforms of G3P detected in the proteomic maps. decrease of Annexin A1, which is mainly involved in oxidative stress responses and apoptosis, may be related to the observed attenuation of HSP expression levels [36].

One other category of interest is that of the calcium binding proteins, including calmodulin and some protein forms of the S100 protein family (protein S100-A11, 2 isoforms of S100 calcium-binding protein $\mathrm{A} 4$, and 2 isoforms of S100 calciumbinding protein A6). These were generally unchanged, except S10A6 which appeared downregulated, as reported by other authors in different types of tumor [37,38].

The class of detoxification and redox proteins included several enzymatic forms and isoforms, most of which remained unchanged in the cocultured cells. However, the superoxide dismutase (SODM) was upregulated, while other members such as aldo-keto reductase family 1 member B10, aldose reductase ( 2 isoforms), aldo-keto reductase family 1 member $\mathrm{C} 3$, and thioredoxin had decreased expression. These responses reflect the complexity of the metabolic dynamism of cells under external influences.

Concerning the other protein categories, a limited number of proteins were influenced by the fibroblastic stimuli. Among these, elongation factor 1-beta and nucleophosmin were downregulated, while the macrophage migration inhibitory factor was upregulated together with proteasome subunit beta type- 4 .

\section{Effect of Coculture on Expression of Cytoskeletal Proteins CK 8 and Vimentin}

Following the proteomic analyses, which revealed that the cytoskeleton and associated proteins (36\% of identified spots) were mostly responsive to the coculture event, we examined 
A

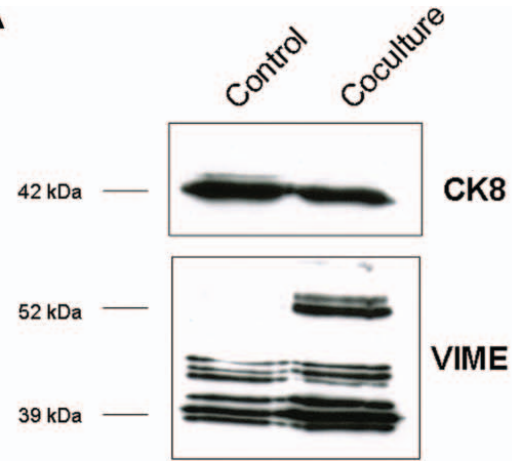

B

8701-BC Control
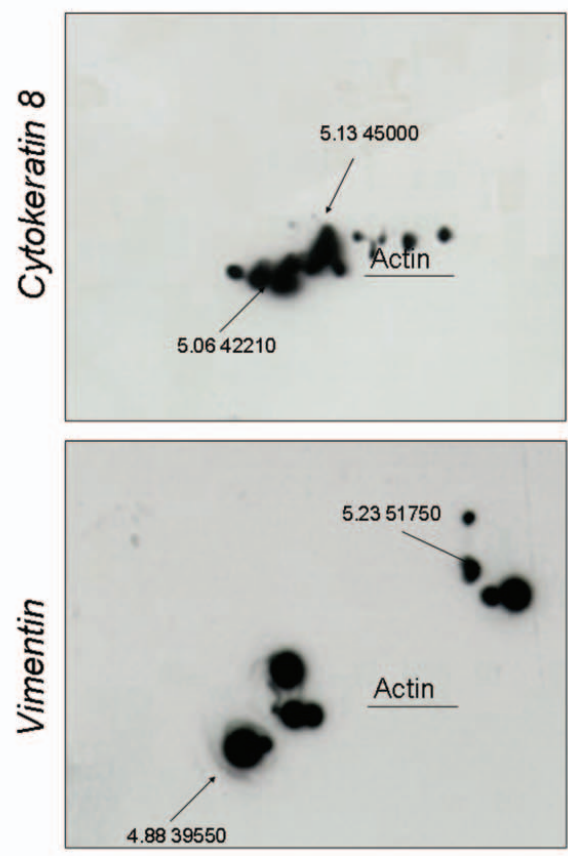

C

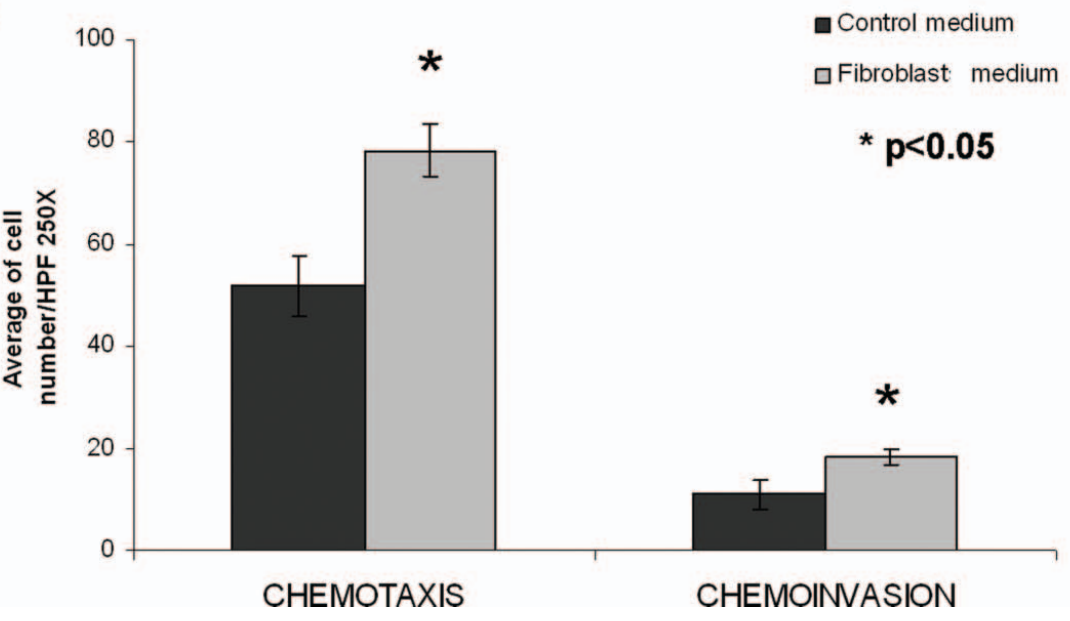

8701-BC Coculture
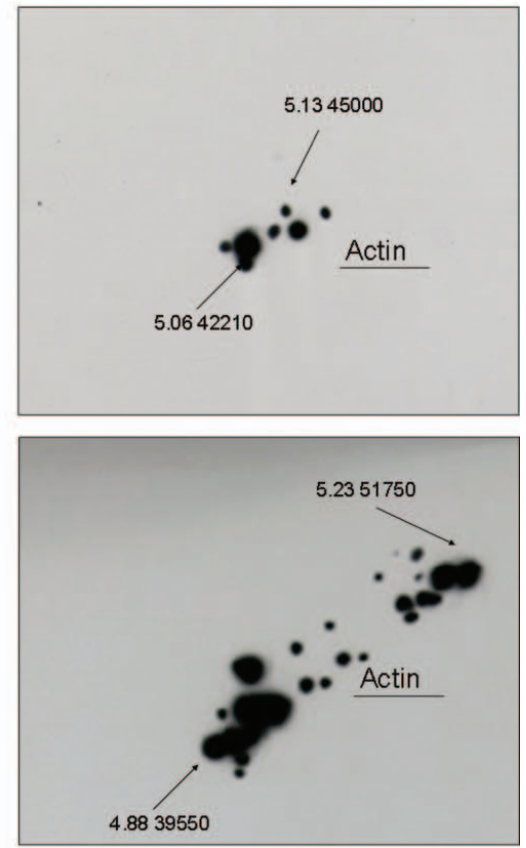

FIG. 5. Panel of Western blots for the immune detection of cytokeratin-8 and vimentin on 8701-BC control cells and cocultured with fibroblasts both in 1-D electrophoresis (A) and 2D electrophoresis (B). Each image of B represents the experimental windows of the Western blot matched with the corresponding silver stained gels for the attribution of $\mathrm{p} / / \mathrm{Mr}$ coordinates. The position of beta-actin is reported for reference. (C) Influence of fibroblast medium on migration and invasion of 8701-BC cells. The ability of cells to migrate through the filter was assayed in the absence and invasion in the presence of a Matrigel layer. The data plotted are the means \pm SD for 3 wells in triplicate experiments under the different conditions. ${ }^{*} p<0.05$. 
the occurrence of cytokeratin 8 and vimentin, which are molecular markers for epithelial and mesenchymal phenotype, respectively, and used in diagnostic histopathology [39-41]. As shown in Figure 5A, there is a general decrement of CK8 immunostaining and a concomitant increment of vimentin forms, following fibroblast stimulation. Bidimensional detection of both proteins revealed the presence of several isoforms for each protein and confirmed a net decrement for the CK8 forms and concurrent increment of vimentin isoforms (Fig. 5B). These results strongly suggest the occurrence of an accentuation of epithelial-mesenchymal transition of 8701-BC cocultured with fibroblasts $[42,43]$.

\section{Fibroblast-Conditioned Medium Effects on 8701-BC Invasion}

To verify if fibroblast effects on intermediate filament transition could also enhance the locomotory and invasive behavior of 8701-BC cells, we performed both migration and matrigel invasion assays, using the Boyden Chamber system. The results obtained (Fig. 5C) clearly demonstrate that fibroblasts significantly increase the invasive potential of the breast cancer cells 8701-BC.

\section{CONCLUSIONS}

There is growing evidence that interactions between tumor cells and the surrounding stromal tissue and cells play a critical role in tumor growth, invasion, metastasis, and angiogenesis. The recruitment of the fibroblasts around the primary site of many tumors has been assigned important roles for carcinogenesis. However, to our knowledge the possible influences of fibroblasts on neoplastic cell behavior have not been exhaustively explored, and there is little information presently available at the proteomic level.

Our report provides the first evidence for multiple effects of fibroblastic stimulation on breast cancer cells, including proteomics, proliferation, and invasion assays. Cell proliferation assays showed a significant increase of growth rate of 8701$\mathrm{BC}$ cells in response to fibroblastic stimulation. Comparative proteomic analyses of control and cocultured cells revealed significant upregulation of several glycolytic enzymes (G3P, TPIS, PGK1). It is well recognized that enhanced glycolytic metabolism, in part due to the upregulation of c-Myc, represents an adaptation to environmental parameters which favors invasive properties of the cancer cells [44], as successfully verified by Boyden chamber migration and invasion assays.

Moreover, the remarkable modulations of proteins belonging to the functional category of cytoskeleton and associated proteins, suggest a dynamic remodelling of the cytoskeleton of cocultured cells, which in turn may be responsible of migratory and invasiveness activities. In fact, conditioned medium produced by fibroblasts successfully stimulated motility and invasion of breast cancer cells, as other authors have previously demonstrated [45].
Interestingly, the categories of molecular chaperones and detoxification were the only two groups which collectively underwent downregulation. They play a fundamental role in the maintenance of cellular homeostasis. In our system, this downregulation suggests an antistress or cytoprotective effect by the fibroblastic factors on breast cancer cells. This is supported by the overexpression of SOD, which might protect cells from toxic damage and induce a pro-survival response.

In conclusion, our present results suggest that epigenetic stimulation mediated by fibroblastic factors enhances the invasive activities of breast cancer cells through cytoskeleton modulation, altered metabolism, increased rate of cell proliferation, migration, and invasive capabilities.

\section{ACKNOWLEDGMENT}

The present research was supported in part by MIUR prot. $\mathrm{N}^{\circ} 2004059221$, and in part by Por Sicilia misura 3.4.

\section{Declaration of Interest}

The authors report no conflicts of interest. The authors alone are responsible for the content and writing of this article.

\section{REFERENCES}

1. Vogelstein, B., and Kinzler, K.W. (1993). The multistep nature of cancer. Trends Genet., 9(4):138-141.

2. Liotta, L.A., and Kohn, E.C. (2001). The microenvironment of the tumourhost interface. Nature, 411(6835):375-379.

3. Gadea, B.B., and Joyce, J.A. (2006). Tumour-host interactions: implications for developing anti-cancer therapies. Expert. Rev. Mol. Med., 8(30):1-32.

4. Tlsty, T.D., and Coussens, L.M. (2006). Tumor stroma and regulation of cancer development. Ann. Rev. Pathol., 1:119-150.

5. De Wever, O., and Mareel, M. (2003). Role of tissue stroma in cancer cell invasion. J. Pathol., 200(4):429-447.

6. Kenny, P.A., and Bissell, M.J. (2003). Tumor reversion: correction of malignant behavior by microenvironmental cues. Int. J. Cancer, 107:688-695.

7. Shekhar, M.P., Pauley, R., and Heppner, G. (2003). Host microenvironment in breast cancer development: extracellular matrix-stromal cell contribution to neoplastic phenotype of epithelial cells in the breast. Breast Cancer Res., 5:130-135.

8. Mazzocca, A., Coppari, R., De Franco, R., Cho, J.Y., Libermann, T.A., Pinzani, M., and Toker, A. (2005). A secreted form of ADAM9 promotes carcinoma invasion through tumor-stromal interactions. Cancer Res., 65(11):4728-4738.

9. Singer, C.F., Kronsteiner, N., Marton, E., Kubista, M., Cullen, K.J., Hirtenlehner, K., Seifert, M., and Kubista, E. (2002). MMP-2 and MMP-9 expression in breast cancer-derived human fibroblast is differentially regulated by stromal-epithelial interactions. Breast Cancer Res. Treat., 72:69-77.

10. Suzuki, S., Sato, M., Senoo, H., and Ishikawa, K. (2004). Direct cell-cell interaction enhances pro-MMP-2 production and activation in co-culture of laryngeal cancer cells and fibroblasts; involvement of EMMPRIN and MT1-MMP. Exp. Cell Res., 293:259-266.

11. Cruz-Munoz, W., Kim, I., and Khokha, R. (2006). TIMP-3 deficiency in the host, but not in the tumor, enhances tumor growth and angiogenesis. Oncogene, 25(4):650-655.

12. Bhowmick, N.A., Chytil, A., Plieth, D., Gorska, A.E., Dumont, N., Shappell, S., Washington, M.K., Neilson, E.G., and Moses, H.L. (2004). TGF-beta signalling in fibroblasts modulates the oncogenic potential of adjacent epithelia. Science, 303:848-851. 
13. Gomm, J.J., Browne, P.J., Coope, R.C., Bansal, G.S., Yiangou, C., Johnston, C.L., Mason, R., and Coombes, R.C. (1997). A paracrine role for myoepitheal cell-derived FGF2 in the normal human breast. Exp. Cell Res., 234:165-173.

14. Scotton, C.J., Wilson, J.L., Scott, K., Stamp, G., Wilbanks, G.D., Fricker, S., Bridger, G., and Balkwill, F.R. (2002). Multiple actions of the chemokine CXCL12 on epithelial tumor cells in human ovarian cancer. Cancer Res., 62:5930-5938.

15. Che, Z.M., Jung, T.H., Choi, J.H., Yoon do, J., Jeong, H.J., Lee, E.J., and Kim, J. (2006). The tumor microenvironment: CXCR4 is associated with distinct protein expression patterns in neuroblastoma cells. Biochem. Biophys. Res. Commun., 346:268-275.

16. Fontana, S., Pucci-Minafra, I., Becchi, M., Freyria, A.M., and Minafra, S. (2004). Effect of collagen substrates on proteomic modulation of breast cancer cells. Proteomics, 4(3):849-860.

17. Pucci-Minafra, I., Fontana, S., Cancemi, P., Alaimo, G., and Minafra, S. (2002). Proteomic patterns of cultured breast cancer cells and epithelial mammary cells. Ann. NY Acad. Sci., 963:122-139.

18. Kumar, S., Mohan, A., and Guleria, R. (2006). Biomarkers in cancer screening, research and detection: present and future: a review. Biomarkers, 11(5):385-405.

19. Minafra, S., Morello, V., Glorioso, F., La Fiura, A.M., Tomasino, R.M., Feo, S., McIntosh, D., and Woolley, D.E. (1989). A new cell line (8701-BC). from primary ductal infiltrating carcinoma of human breast. Br. J. Cancer., 60(2):185-192.

20. Boraldi, F., Bini, L., Liberatori, S., Armini, A., Pallini, V., Tiozzo, R., Ronchetti, I.P., and Quaglino, D. (2003). Normal human dermal fibroblasts: proteomic analysis of cell layer and culture medium. Electrophoresis., 24(7-8):1292-1310.

21. Bradford, M.M. (1976). A rapid and sensitive method for the quantitation of microgram quantities of protein utilizing the principle of protein-dye binding. Anal. Biochem., 72:248-254.

22. Shevchenko, A., Wilm, M., Vorm, O., and Mann, M. (1996). Mass spectrometric sequencing of proteins silver-stained polyacrylamide gels. Anal. Chem., 68(5):850-858.

23. Blancato, J., Singh, B., Liu, A., Liao, D.J., and Dickson, R.B. (2004). Correlation of amplification and overexpression of the c-myc oncogene in high-grade breast cancer: FISH, in situ hybridisation and immunohistochemical analyses. Br. J. Cancer, 90:1612-1619.

24. De Nigris, F., Sica, V., Herrmann, J., Condorelli, G., Chade, A.R., Tajana, G., Lerman, A., Lerman, L.O., and Napoli, C. (2003). c-Myc oncoprotein: cell cycle-related events and new therapeutic challenges in cancer and cardiovascular diseases. Cell Cycle., 2(4):325-328.

25. Pucci-Minafra, I., Cancemi, P., Fontana, S., Minafra, L., Feo, S., Becchi, M., Freyria, A.M., and Minafra, S. (2006). Expanding the protein catalogue in the proteome reference map of human breast cancer cells. Proteomics, 6(8):2609-2625.

26. Pucci-Minafra, I., Cancemi, P., Marabeti, M.R., Albanese, N.N., Di Cara, G., Taormina, P., and Marrazzo, A. (2006). Proteomic profiling of 13 paired ductal infiltrating breast carcinomas and non-tumoral adjacent counterparts. Proteomics Clin. Appl., 1:118-129.

27. Wheelock, A.M., and Goto, S. (2006). Effects of post-electrophoretic analysis on variance in gel-based proteomics. Expert Rev. Proteomics, (1):129-142.

28. Chang, J., Van Remmen, H., Ward, W.F., Regnier, F.E., Richardson, A., and Cornell, J. (2004). Processing of data generated by 2-dimensional gel electrophoresis for statistical analysis: missing data, normalization, and statistics. J. Proteome Res., 3:1210-1218.

29. Pucci-Minafra, I., Cancemi, P., Di Cara, G., Minafra, L., Feo, S., Forlino, A., Tira, M.E., Tenni, R., Martini, D., Ruggeri, A., and Minafra, S. (2008). Decorin transfection induces proteomic and phenotypic modulation in breast cancer cells 8701-BC. Connect. Tissue Res., 49(1):30-41.

30. Lin, J.J., Eppinga, R.D., Warren, K.S., and McCrae, K.R. (2008). Human tropomyosin isoforms in the regulation of cytoskeleton functions. Adv. Exp. Med. Biol., 644:201-222.

31. Huang, L.E. (2008). Carrot and stick: HIF-alpha engages c-Myc in hypoxic adaptation. Cell Death Differ, 15(4):672-677.

32. Gillies, R.J., and Gatenby, R.A. (2007). Adaptive landscapes and emergent phenotypes: why do cancers have high glycolysis? J. Bioenerg. Biomembr., 39(3):251-257.

33. Lahav, J., Gofer-Dadosh, N., Luboshitz, J., Hess, O., and Shaklai, M. (2000). Protein disulfide isomerase mediates integrin dependent adhesion. FEBS Lett., 475:89-92.

34. Goplen, D., Wang, J., Enger, P.Ø., Tysnes, B.B., Terzis, A.J., Laerum, O.D., and Bjerkvig, R. (2006). Protein disulfide isomerase expression is related to the invasive properties of malignant glioma. Cancer Res., 66(20):9895-9902.

35. Hayes, M.J., Shao, D., Bailly, M., and Moss, S.E. (2006). Regulation of actin dynamics by annexin 2. EMBO J., 25:1816-1826.

36. Rhee, H.J., Kim, G.Y., Huh, J.W., Kim, S.W., and Na, D.S. (2000). Annexin I is a stress protein induced by heat, oxidative stress and a sulfhydryl-reactive agent. Eur. J. Biochem., 267:3220-3225.

37. Sapkota, D., Bruland, O., Bøe, O.E., Bakeer, H., Elgindi, O.A., Vasstrand, E.N., and Ibrahim, S.O. (2008). Expression profile of the S100 gene family members in oral squamous cell carcinomas. J. Oral. Pathol. Med., 37(10):607-615.

38. Carlsson, H., Petersson, S., and Enerbäck, C. (2005). Cluster analysis of S100 gene expression and genes correlating to psoriasin (S100A7) expression at different stages of breast cancer development. Int. J. Oncol., 27(6): 1473-1481.

39. Skinnider, B.F., Folpe, A.L., Hennigar, R.A., Lim, S.D., Cohen, C., Tamboli, P., Young, A., de Peralta-Venturina, M., and Amin, M.B. (2005). Distribution of cytokeratins and vimentin in adult renal neoplasms and normal renal tissue: potential utility of a cytokeratin antibody panel in the differential diagnosis of renal tumors. Am. J. Surg. Pathol., 29(6):747-754.

40. Moll, R., Franke, W.W., Schiller, D.L., Geiger, B., and Krepler, R. (1982). The catalog of human cytokeratins: patterns of expression in normal epithelia, tumors and cultured cells. Cell, 31:11-24.

41. Coulombe, P.A., and Omary, M.B. (2002). 'Hard' and 'soft' principles defining the structure, function and regulation of keratin intermediate filaments. Curr. Opin. Cell Biol., 14:110-122.

42. Kraut, N., Beug, H., and Huber, M.A. (2005). Molecular requirements for epithelial-mesenchymal transition during tumor progression. Curr. Opin. Cell Biol., 17(5):548-558.

43. Vincent-Salomon, A., and Thiery, J.P. (2003). Host microenvironment in breast cancer development: epithelial-mesenchymal transition in breast cancer development. Breast Cancer Res., 5(2):101-106.

44. Gatenby, R.A., and Gillies, R.J. (2004). Why do cancers have high aerobic glycolysis? Nat. Rev. Cancer., 4(11):891-899.

45. Heylen, N., Baurain, R., Remacle, C., and Trouet, A. (1998). Effect of MRC-5 fibroblast conditioned medium on breast cancer cell motility and invasion in vitro. Clin Exp Metast, 16(2):193-203. 